\title{
PREDICTION OF CUMULONIMBUS (CB) CLOUD BASED ON INTEGRATED FORECAST SYSTEM (IFS) OF EUROPEAN MEDIUM- RANGE WEATHER FORECAST (ECMWF) IN THE FLIGHT INFORMATION REGION (FIR) OF JAKARTA AND UJUNG PANDANG
}

\author{
Prediksi Awan Cumulonimbus (Cb) Berbasis Model Integrated Forecast \\ System (IFS) European Medium-Range Weather Forecast (ECMWF) Pada \\ Flight Information Region (FIR) Jakarta dan Ujung Pandang
}

\author{
Achmad Fahruddin Rais ${ }^{1)^{\star}}$, Fani Setiawan ${ }^{1)}$, Rezky Yunita $^{1)}$, Erika Meinovelia ${ }^{1)}$, Soenardi ${ }^{1)}$, \\ Muhammad Fadli', Bambang Wijayanto ${ }^{1)}$ \\ ${ }^{1)}$ Badan Meteorologi Klimatologi dan Geofisika. Jl. Angkasa I No.2 Kemayoran, Jakarta Pusat 10720 \\ *E-mail: achmad.rais@bmkg.go.id
}

\begin{abstract}
This study was focused on cumulonimbus (Cb) cloud prediction based on Integrated Forecast System (IFS) European Medium-Range Weather Forecast (ECMWF) model in the Flight Information Region (FIRs) Jakarta and Ujung Pandang. The Cb cloud prediction was calculated using convective cloud cover (CC) of the precipitation product. The model predictability was examined through categorical verification. The Cb cloud observation was based on brightness temperature (BT) IR1 and brightness temperature difference (BTD) IR1-IR2. The results showed that CC 50\%' predictor was the best predictor to estimate the Cb cloud. The study in the period other than 2019 is suggested for the next research because Indian Ocean Dipole (IOD) is extreme that may affect the Cb cloud growth in the study area.
\end{abstract}

Keywords: Cumulonimbus, Integrated Forecast System, Flight Information Region

\section{Intisari}

Studi ini berfokus pada prediksi awan cumulonimbus (Cb) berbasis model Integrated Forecast System (IFS) European Medium-Range Weather Forecast (ECMWF) pada Flight Information Region (FIR) Jakarta dan Ujung Pandang. Prediksi awan Cb menggunakan perhitungan convective cloud cover (CC) dari produk presipitasi. Kemampuan prediksi model diuji dengan menggunakan verifikasi kategorik terhadap observasi awan Cb dari brightness temperature (BT) IR1 dan brightness temperature difference (BTD) IR1-IR2. Hasil studi menunjukkan bahwa prediktor CC 50\% merupakan prediktor terbaik untuk memprediksi awan Cb. Kajian pada periode selain 2019 disarankan pada kajian selanjutnya karena Indian Ocean Dipole (IOD) bersifat ekstrim pada periode tersebut yang memungkinkan mempengaruhi pertumbuhan awan Cb di wilayah kajian.

Kata Kunci: Cumulonimbus, Integrated Forecast System, Flight Information Region

\section{INTRODUCTION}

Cumulonimbus $(\mathrm{Cb})$ cloud is a kind of cloud influencing the aircraft flight operational. A thunderstorm appearing from $\mathrm{Cb}$ is the main factor of the take-off delay of aircraft (Peck, 2015). The delay can cause a high disadvantage for the flight operation (Evans, 1995 and Klein et al., 2009). Cb can produce microbursts with lowlevel turbulence, severe icing, lightning, high liquid water, and hail (Bhawan, 2013). In the cruising and descending phases, in-cloud turbulence is the most factor in aircraft accidents (Mazon et al., 2018). Cb is also a potential cloud producing severe turbulence (WMO, 2018).
Therefore, the $\mathrm{Cb}$ prediction is a necessity for the safety and efficiency of the flight operation.

In the research of Eastman and Warren (2014), a comparison of several pictures have shown that Indonesia is one of the distribution areas of a significant number of $\mathrm{Cb}$ clouds both over land and sea. $\mathrm{Cb}$ clouds' distribution has seasonal characteristics concluded to be triggered by monsoons (Sipayung and Risyanto, 2014). The distribution of lightning originating from $\mathrm{Cb}$ is also most common in Indonesia (Christian et al., 2003). Therefore, the research on $\mathrm{Cb}$ prediction in Indonesia is very interesting.

The World Area Forecast Centers (WAFC) London and Washington have issued blended $\mathrm{Cb}$ predictions up to 36 hours (Met Office and 
NOAA, 2012). However, the output of the dissemination model used has a coarse resolution $\left(1.25^{\circ}\right)$. Therefore, we will examine the use of European Medium-Range Weather Forecast (ECMWF) Integrated Forecast System (IFS) products with better resolution $\left(0.125^{\circ}\right)$.

This study investigates the prediction performance of the $\mathrm{Cb}$ cloud based on the IFS ECMWF model on Jakarta and Ujung Pandang Flight Information Region (FIRs). The ECMWF IFS model is a high resolution (HRES) model issued by ECMWF with a $9 \mathrm{~km}$ cycle $41 \mathrm{r} 2$. In its dissemination, the model resolution was changed to $0.125^{\circ}(13.5 \mathrm{~km})$. This model is processed with initial conditions at 00UTC and 12UTC. HRES also uses couplings with Dynamic Ocean models (NEMO) and Wave models (ECWAM). This model uses the assimilation of 4-DVar, which involves many cloud-sensitive observations and precipitation (Geer et al., 2017). Information about IFS ECMWF HRES can be found on the web page https://confluence.ecmwf.int//display/FUG/HRES +-+High-Resolution+Forecast

\section{METHOD}

As an input processing in the research, we used satellite data Himawari-8 channels IR1 $(10.4 \mu \mathrm{m})$, IR2 $(12.4 \mu \mathrm{m})$ and IFS ECMWF HRES every 3 hours of the prediction of the 6th hour $(T+6)$ to the 36th hour $(T+36)$ with initial conditions of 00 UTC and 12 UTC on the first day of each month in 2019. The study location was Jakarta and Ujung Pandang FIRs and was limited by the polygon lines in Figure 1.

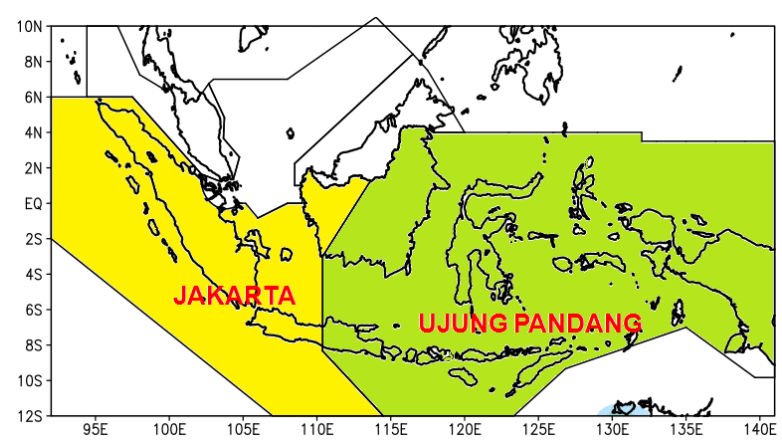

Figure 1. Jakarta (yellow) and Ujung Pandang (green) Flight Information Regions.

To get observations of $\mathrm{Cb}$ cloud coverage, we used a combination of brightness temperature (BT) IR1 channel and brightness temperature difference (BTD) IR1-IR2 satellite Himawari-8. Inoue (1987) used a $250^{\circ} \mathrm{K}$ threshold for BT IR1 and $0^{\circ} \mathrm{K}$ to $0.5^{\circ} \mathrm{K}$ for BTD IR1-IR2. In the subsequent research, Inoue (1989) changed the BTD IR1-IR2 threshold to $0^{\circ} \mathrm{K}$ to $1^{\circ} \mathrm{K}$ and BT IR1 threshold to $-20^{\circ} \mathrm{C}$. Hamada et al. (2004) used threshold $0^{\circ} \mathrm{K}$ to $0.5^{\circ} \mathrm{K}$ for BTD IR1-IR2 and $259^{\circ} \mathrm{K}$ for BT IR1. Suseno and Yamada (2012) made a $\mathrm{Cb}$ classification with traces of $-2^{\circ} \mathrm{K}$ to $2^{\circ} \mathrm{K}$ for BTD IR1-IR2 and $245^{\circ} \mathrm{K}$ for BT IR1. Purbantoro et al. (2019) limited the $\mathrm{Cb}$ classification to $0.6^{\circ} \mathrm{K}\left(0.9^{\circ} \mathrm{K}\right)$ for BTD IR1-IR2 and $253^{\circ} \mathrm{K}\left(258^{\circ} \mathrm{K}\right)$ for BT IR1 in winter (summer). From all the $\mathrm{Cb}$ cloud determination thresholds, we used all the maximum threshold values of previous studies with $-2^{\circ} \mathrm{K}$ to $2^{\circ} \mathrm{K}$ for BTD IR1-IR2 and $259^{\circ} \mathrm{K}$ for BT IR1 (Figure 2 ).

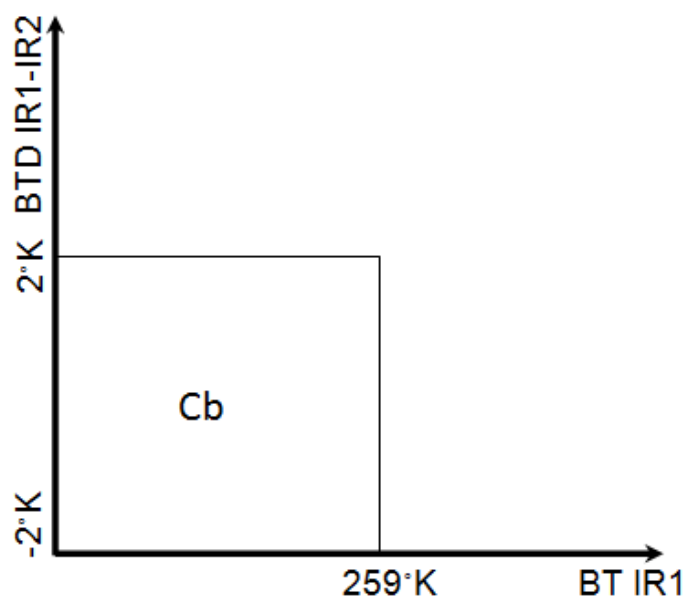

Figure 2. Ilustrated graph of $\mathrm{Cb}$ based on BTD IR1-IR2 and BT IR1.

The method used to estimate the spread of the $\mathrm{Cb}$ cloud was convective cloud cover (CC) in Slingo and Slingo (1991). WAFC London also used a formulation of precipitation relationship with CC (Maisey, 2012). We used CC 40\%, 50\%, and $60 \%$ for $\mathrm{Cb}$ cloud prediction. The $\mathrm{CC}$ was then synchronized with the total cloud cover (40\%, 50\%, and 60\%) of the IFS ECMWF HRES output model through an intersection between the estimated CC and the total cloud cover.

Table 1. Contigency table

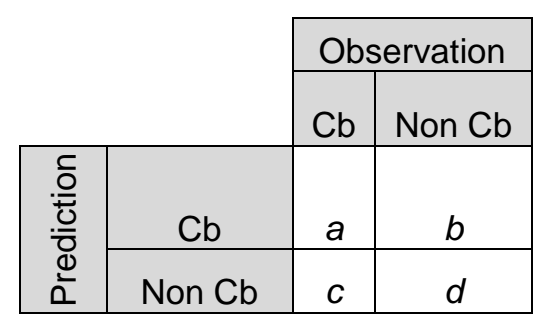

We conducted verification of all prediction data of IFS ECMWF HRES every 3 hours of predicting the 6th hour $(T+6)$ to the 36th hour $(T+36)$ with initial conditions of 00 UTC and 12 UTC on the first day of each month in 2019. The verification was processed by comparing the frequency and calculating qualitative values from the contingency table in table 1 . We used the probability of detection (POD), probability of false detection (POFD), and percent correct (PC) sourced from https: // www.cawcr.gov.au/projects/verification/\#Methods for_dichotomous_forecasts. 
$P O D=\frac{a}{a+c}$

$$
\text { POFD }=\frac{b}{b+d}
$$

$$
P C=\frac{a+d}{a+b+c+d}
$$

POD was a measure of a model's ability to predict the probability of a $\mathrm{Cb}$ cloud with a maximum value of 1 . In contrast, POFD was a measure of a model's ability to predict the probability of the absence of a $\mathrm{Cb}$ cloud with a maximum value was 0 . POD and POFD values could be $0 / 0$ or undefined. We marked it as a white color in Figure 4. Simultaneously, the PC was a measure of model accuracy because of the model's ability to predict the presence and absence of the $\mathrm{Cb}$ cloud. PC had a maximum value of 1 .

\section{RESULT AND DISCUSSION}

Figure 3 shows that the $\mathrm{Cb}$ frequency of CC $40-60 \% T+6$ to $T+36$ tends to overestimate Jakarta and Ujung Pandang FIRs to satellitebased $\mathrm{Cb}$ frequencies. It seems that the $\mathrm{Cb}$ frequency of CC $60 \%$ is the closest. In general, the $\mathrm{Cb}$ cloud frequency spatial pattern can be captured by models that show smaller $\mathrm{Cb}$ cloud frequencies in the southern part of Jakarta and Ujung Pandang FIRs and also the northern waters of Celebes and Mollucas.
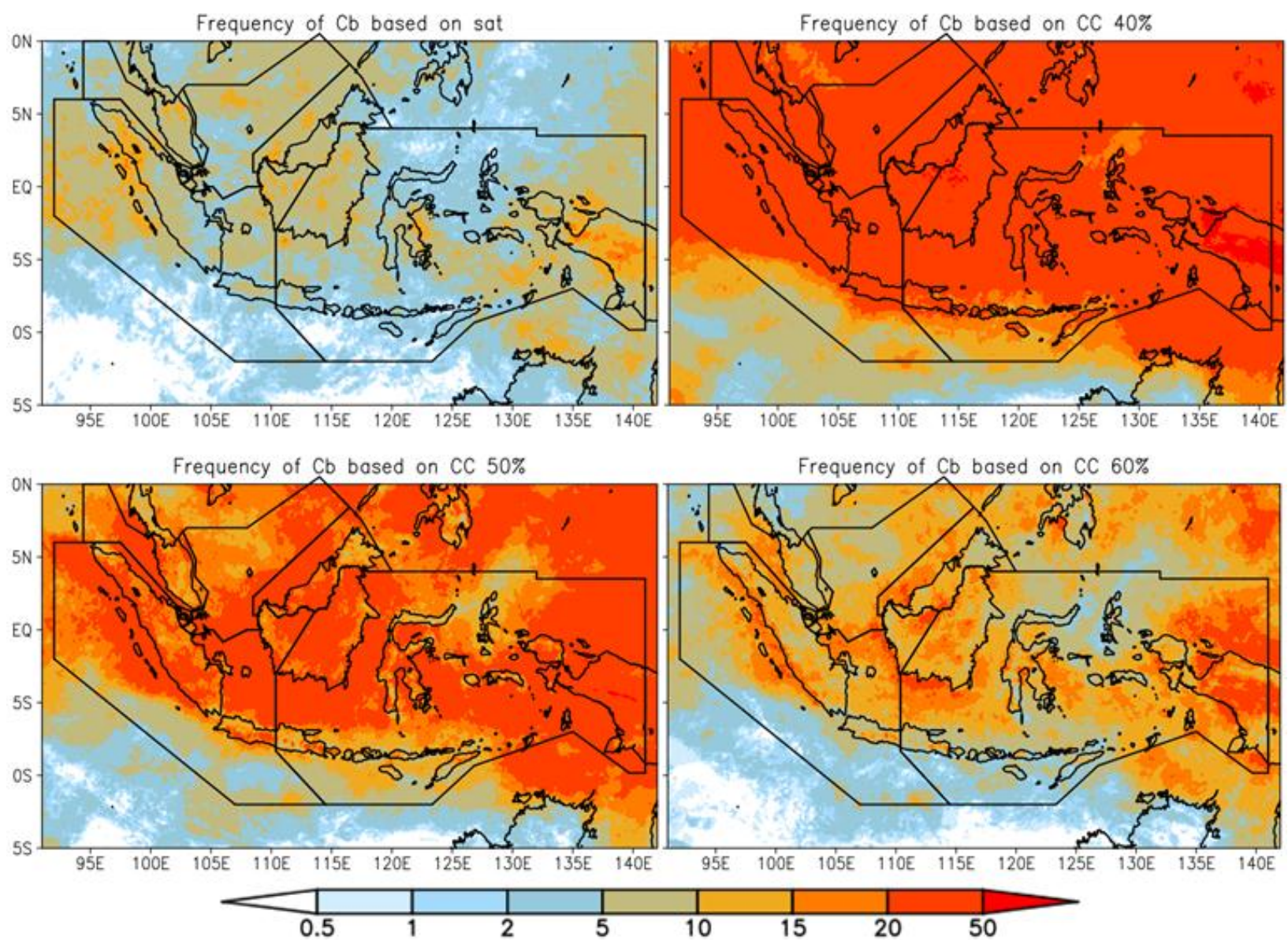

Figure 3. $\mathrm{Cb}$ frequencies (\%) of Satellite and CC $40 \%, 50 \%$, and $60 \%$ for $T+6$ to $T+36$. 


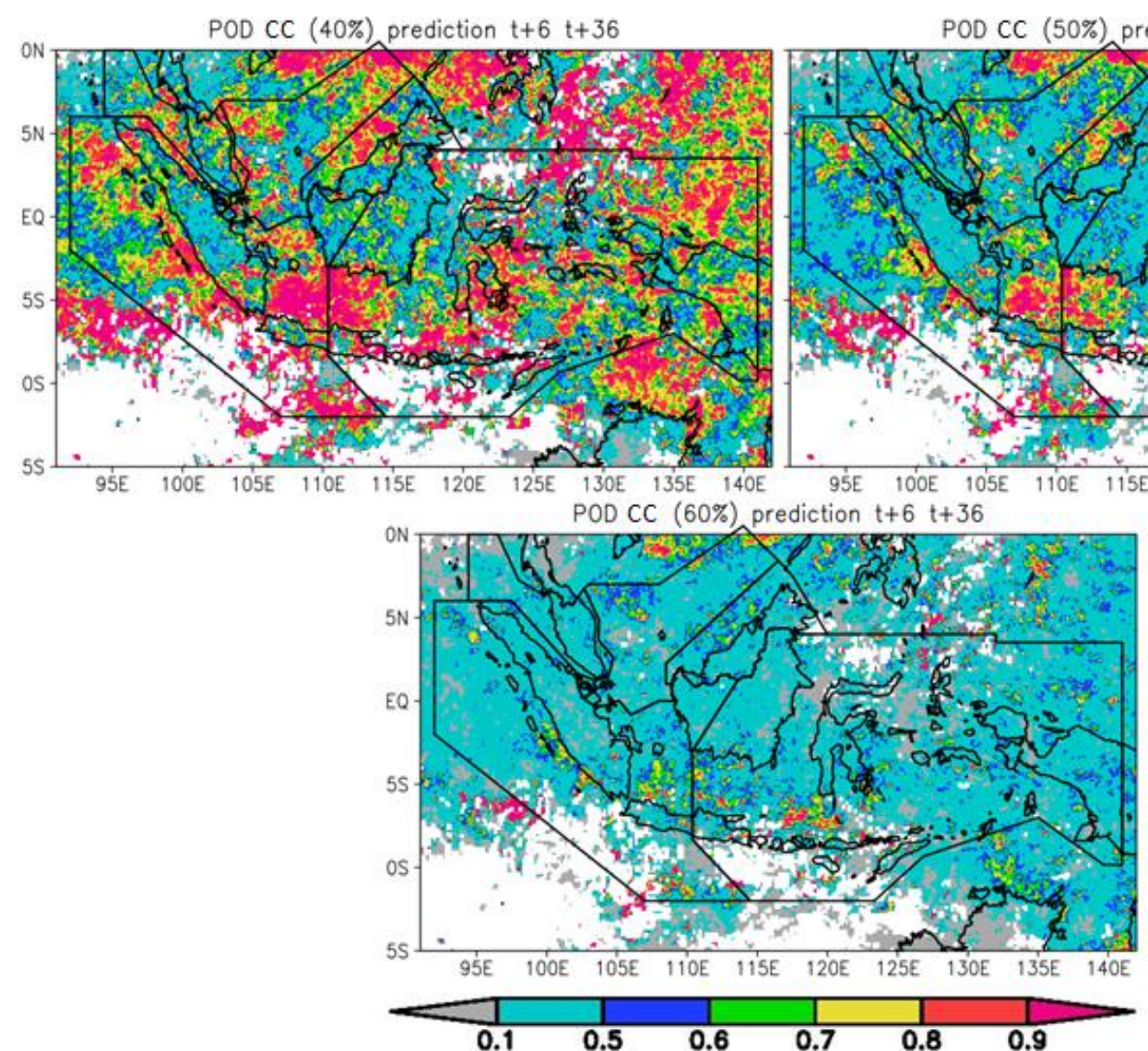

Figure 4. PODs of CC $40 \%, 50 \%$, and $60 \%$ for $T+6$ to $T+36$.

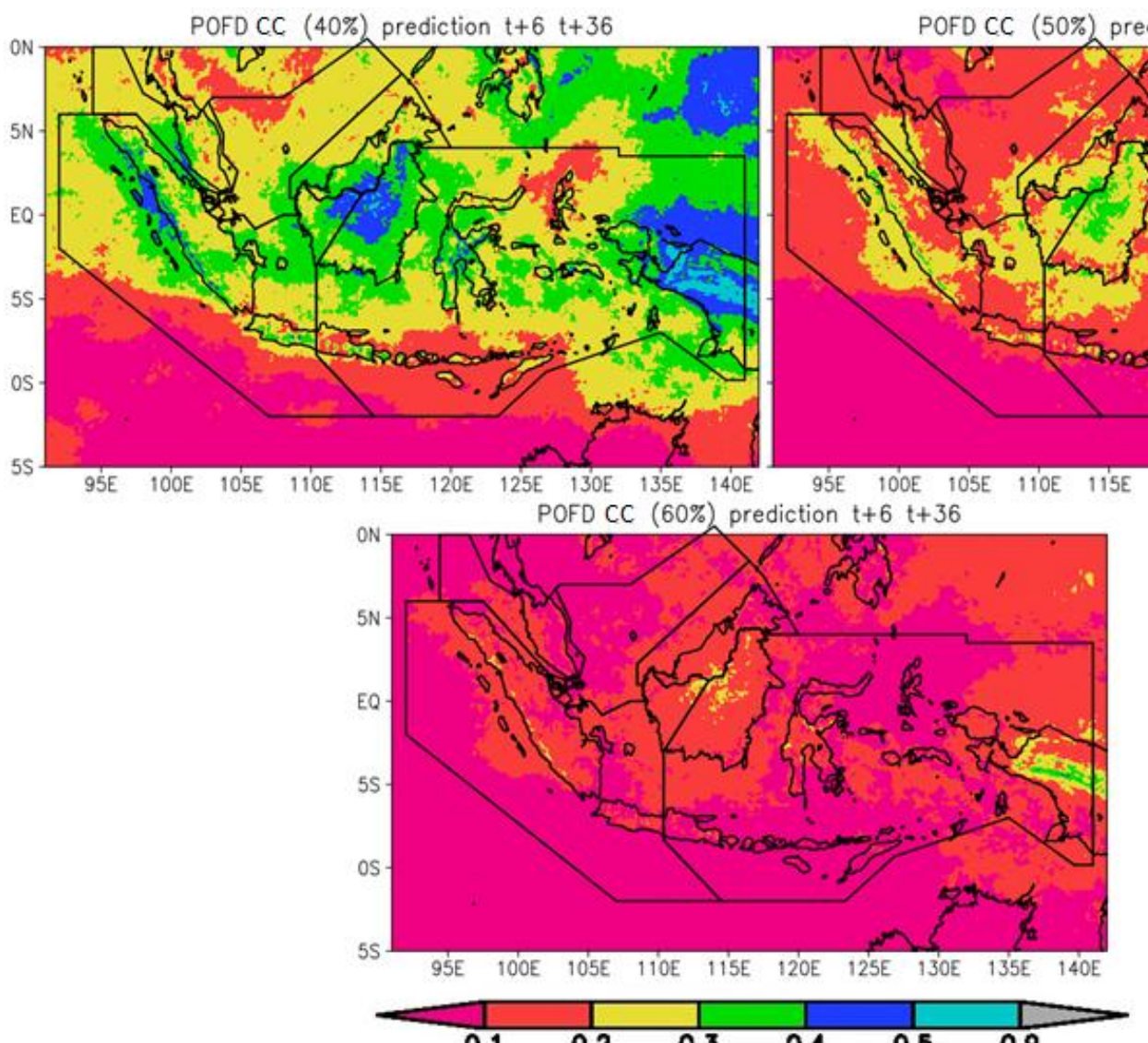

Figure 5. POFDs of CC $40 \%, 50 \%$, and $60 \%$ for $T+6$ to $T+36$. 

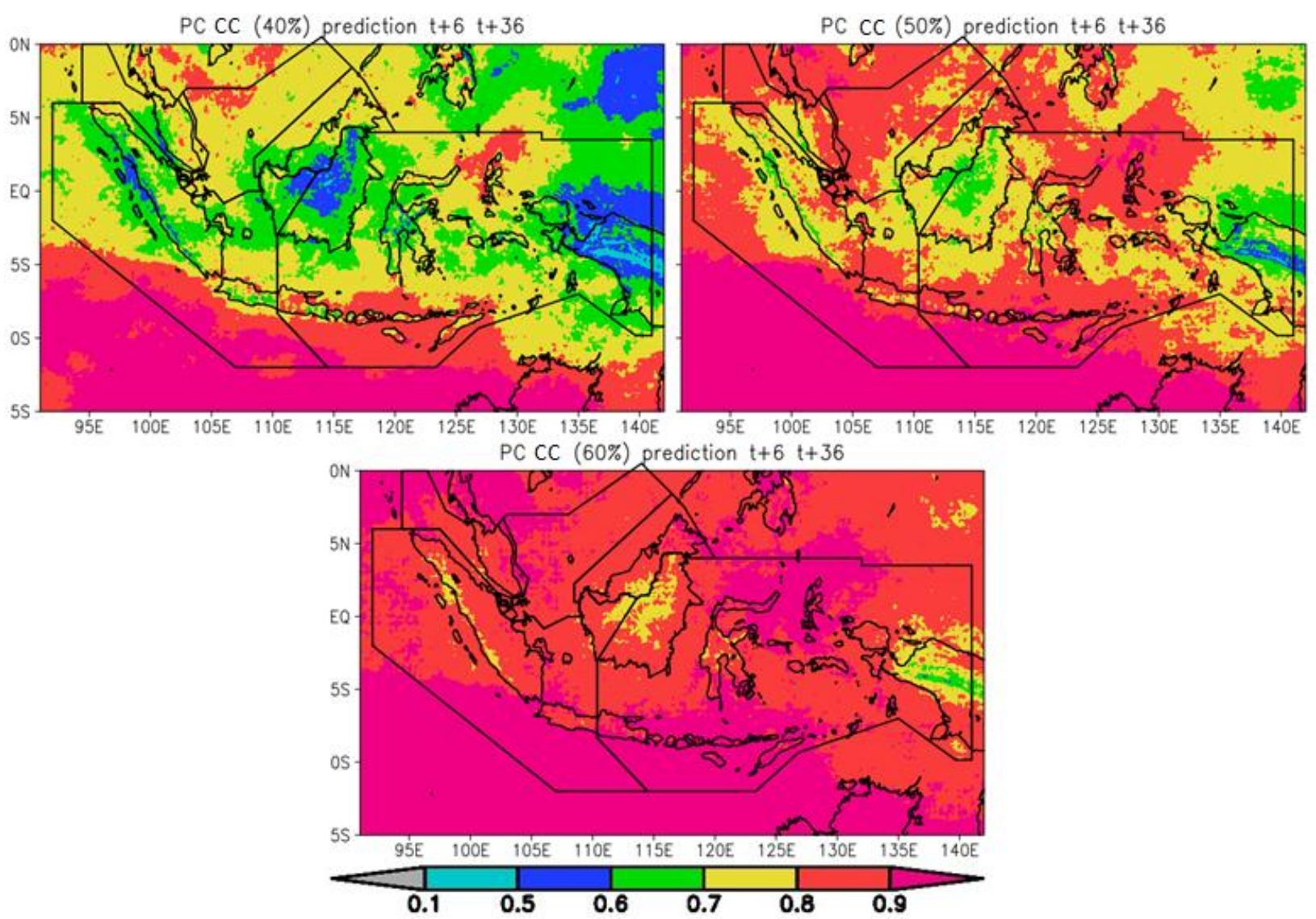

Figure 6. PCs of CC $40 \%, 50 \%$, and $60 \%$ for $T+6$ to $T+36$.

Figure 4 shows that the POD of CC $40 \%$ $>0.9$ is generally distributed in the waters, both in Jakarta and Ujung Pandang FIRs. Only a small portion is spread evenly on the islands. Whereas the POD of CC $40 \%<0.5$ is mostly over the islands. The POD of CC $50 \%>0.9$ is also distributed in the waters but with a smaller area than the CC $40 \%>0.9$. In contrast, the POD spatial distribution of CC $50 \%<0.5$ is wider than the POD of CC $40 \%<0.5$. The POD of CC $60 \%<0.5$ seems to dominate the entire Jakarta and Ujung Pandang FIRs, only a small area is $>0.9$. In the Maisey study (2012), the $\mathrm{Cb}$ blended PODs of WAFC for CC $40-60 \%$ were in June-July-August (JJA) 2010, JJA 2011, and December-January-February (DJF) 2011-2012 around $0.7,0.7$, and 0.05 . The POD of WAFC on the DJF is very small, whereas the DJF is the dominant period of the maximum phase of the $\mathrm{Cb}$ cloud frequency in Indonesia (Suaydhi et al., 2015). Comparing the PODs of WAFC to Figure 5 shows that CC $40 \%$ and $50 \%$ can produce $P O D \geq 0.7$, which is widely distributed in Jakarta and Ujung Pandang FIRs.

Figure 5 shows the opposite. In general, the POFD of CC $40 \%$ is more significant than CC $50 \%$ and $60 \%$. Most of the POFD $<0.3$ is indicated by CC $50 \%$, although the POFD $>0.5$ is also indicated by CC $50 \%$ in central Papua. In contrast, the POFD of CC $60 \%$ has a very low value dominated by values $<0.2$. Compared to the blended Cb POFD of WAFC for CC $40-60 \%$ in June-July-August (JJA) 2010, JJA 2011, and
December-January-February (DJF) 2011-2012, which are $0.15,0.25$, and 0 (Maisey, 2012), the CC $50-60 \%$ can produce POFD $<0.2$ which is dominant in the study area.

The PC in Figure 6 has a color distribution similar to Figure 6 but with an inverse value. This indicates that $d$ in table 1 dominates the PC. The PC of CC $40 \%$ generally has the smallest value even though most of the values are still $>0.6$, except in western Sumatra waters, central Borneo, central Papua, and northern Papua waters. The PC of CC $50 \%$ and $60 \%$ are generally $>0.7$ and $>0.8$ and $<0.5$ that is also found in central Papua. The PC of CC $60 \%>0.7$ is mostly in Jakarta and Ujung Pandang FIRs.

\section{CONCLUSION}

In this research, we examined the predictability of $\mathrm{Cb} \mathrm{T}+6$ to $\mathrm{T}+36$ based on $\mathrm{CC} 40$ $60 \%$ calculated from the IFS ECMWF HRES model's predicted precipitation through a comparison of frequency, POD, POFD, and PC. Because the CC $50 \%$ had a better frequency than CC $60 \%$, its POD $\geq 0.7$ which was quite widely spread in the study area, and its POFD $<0.2$ and $P C>0.7$ were dominant in Jakarta and Ujung Pandang FIRs, we concluded that the CC $50 \%$ was the best predictor of $\mathrm{Cb}$.

Besides the CC $50 \%$ had a better spatial resolution than the WAFC product, the CC $50 \%$ 
also showed better accuracy through higher POD and lower POFD. This result indicated that CC $50 \%$ of the IFS ECMWF model could be used for the operational aviation meteorology over the Jakarta and Ujung Pandang FIRs.

This research was conducted in the 2019 period, an extreme Indian Ocean Dipole (IOD) period. It might affect the $\mathrm{Cb}$ cloud frequency. So the next study is suggested to involve the neutral period of IOD.

\section{REFERENCE}

Bhawan, Mausam. (2013). Lecture Notes on Aviation Meteorology. Central Aviation Meteorological Division India Meteorological Department.

Christian, H.J., Blakeslee, R.J., Boccippio, D.J., Boeck, W.L., Buechler, D.E., Driscoll, K.T., Goodman, S.J., Hall, J.M., Koshak, W.J., Mach, D.M., Stewart, M.F. (2003). Global frequency and distribution of lightning as observed from space by the Optical Transient Detector. Journal of Geophysical Research, 108(D1), 4005. doi:10.1029/2002JD002347.

Eastman, R., Warren, S.G. (2014). Diurnal Cycles of Cumulus, Cumulonimbus, Stratus, Stratocumulus, and Fog from Surface Observations over Land and Ocean. Journal of Climate, 27(6), 23862404. doi: 10.1175/JCLI-D-13-00352.1

Evans, J.E. (1995). Safely reducing delays due to adverse terminal weather, In: Modelling and simulation in air traffic management, Bianco, L., Dell'Olmo, P., Odoni, A.R. (eds), Springer: Berlin Heidelberg, 85-202.

Geer, A., Ahlgrimm, M., Bechtold, P., Bonavita, M., Bormann, N., English, S., Fielding, M., Forbes, R., Hogan, R., Holm, E., Janiskov'a, M., Lonitz, K., Lopez, P., Matricardi, M., Sandu, I., Weston. P. (2017). Assimilating observations sensitive to cloud and precipitation. Technical Memorandum No. $815 . \quad$ doi: 10.21957/sz7cr1dym

Hamada, A.; Nishi, N.; Kida, H.; Shiotani, M.; Iwasaki, S.; Kamei, A.; Ohno, Y.; Kuroiwa, H.; Kumagai, H.; Okmoto, H. (2004). Cloud type classification by GMS-5 infrared split window measurements with millimeterwave radar and TRMM observations in the tropics. Proceedings of the 2nd TRMM International Science Conference, Nara, Japan, 6-10 September 2004.

Inoue, T. (1987). A Cloud Type ClassificationWith NOAA 7 Split-Window Measurements. Journal of Geophysical Research, 92(D4), 3991-4000. 10.1029/JD092iD04p03991

Inoue, T. (1989). Features of Clouds over the Tropical Pacific during Northern
Hemispheric Winter Derived from Split Window Measurements. Journal of the Meteorological Society of Japan, 67(4), 621-637. doi: 10.2151/jmsj1965.67.4_621.

Klein, A., Kavoussi, S., Lee, R.S. (2009). Weather forecast accuracy: study of impact on airport capacity and estimation of avoidable costs. Proceeding of the Eighth USA/Europe Air Traffic Management Research and Development Seminar.

Maisey, P. (2012). Operational implementation of harmonised WAFS gridded products. Working paper at World Area Forecast System Operations Group (WAFSOPSG) Seventh Meeting.

Mazon, J., Rojas, J. I., Lozano, M., Pino, D., Prats, X., Miglietta, M.M. (2018). Influence of meteorological phenomena on worldwide aircraft accidents, 1967-2010. Meteorological Application. doi: 10.1002/met.1686

Met Office, NOAA. (2016). Guidance on the Harmonized WAFS Grids for Cumulonimbus Cloud, Icing and Turbulence Forecasts Version 2.6.

Peck, L. (2015). The Impacts of Weather On Aviation Delays At O.R. Tambo International Airport, South Africa. Master Thesis. University of South Africa.

Purbantoro, B., Aminuddin, J., Manago, N., Toyoshima, K., Lagrosas, N., Josaphat Sumantyo, T.S., Kuze, H. (2019). Comparison of Aqua/Terra MODIS and Himawari-8 Satellite Data on Cloud Mask and Cloud Type Classification Using Split Window Algorithm. Remote Sens. 11, 2944. doi: 10.3390/rs11242944.

Sipayung, S. B., Risyanto. (2014). Frequency Distribution of Type $\mathrm{Cb}$ From Satellite Observation MTSAT in Indonesia. National Space and Atmospherical Science Seminar 2014.

Slingo, A., Slingo, J.M. (1991). Response of the National Center for Atmospheric Research Community Climate Model to Improvements in the Representation of Clouds. Journal of Geophysical Research, 96(D8). doi: 10.1029/91JD00930.

Suaydhi, F. Lesmono, A. Nafiisyanti. (2015). Variasi Musiman Berbagai Jenis Awan di Indonesia dalam Fisika, Kimia dan Dinamika Atmosfer di Indonesia. Bandung: Pusat Sains dan Teknologi Atmosfer, LAPAN.

Suseno, D.P.W., Yamada, T.J. (2012). Twodimensional, threshold-based cloud type classification using MTSAT data. Remote Sensing Letters 3(8). doi: 10.1080/2150704X.2012.698320.

World Meteorological Organization (WMO). (2018). Aviation Hazards. AeM Series No. 3. Geneva: WMO. 